Gadjah MadaInternational Journal of Business

September-December 2010, Vol. 12, No. 3,pp.415-434

\title{
THE MODERATING EFFECT OF PROCEDURAL JUSTICE ON THE EFFECTIVENESS OF THE BALANCED SCORECARD IN IMPROVING MANAGERIAL PERFORMANCE THROUGH ORGANIZATIONAL COMMITMENT
}

\author{
Supriyadi \\ Faculty of Economics and Business, Universitas Gadjah Mada, Yogyakarta, Indonesia
}

This study extends prior studies on the effectiveness of the Balanced Scorecard (BSC) to improve managerial performance done by Lau and Mosser (2008) and Lau and Sholihin (2005). Specifically, the study empirically tests the moderating effects of procedural justice on the relationship between the financial and nonfinancial dimensions of BSC and managerial performance. It also tests the impact of organizational commitment on performance. Based on survey data from 76 respondents, the results indicate that perceived procedural justice in the use financial and nonfinancial dimensions of the BSC is associated with managers' organizational commitment. It further finds that organizational commitment is positively related to performance. The study extends the literature by providing empirical evidence about the moderating effect of procedural justice on the relationship between the financial and nonfinancial dimensions of BSC and organizational commitment.

Keywords: balanced scorecard; organizational commitment; financial measures; managerial performance; moderating effect; nonfinancial measures; procedural justice

\footnotetext{
* I thank the editor and two anonymous reviewers for their helpful comments and suggestions
} 


\section{Introduction}

Since Kaplan and Norton (1992) introduced the balanced scorecard (BSC), more companies have replaced their traditional financial performance measures with the BSC. Prior studies found that 44 percent of organizations in the US (Rigby 2001) and 35 percent of large US firms (Marr et al. 2004) use the BSC. Silk(1998 in Lipe and Salterio 2000) indicated that the BSC has been widely used by around 60 percent of US Fortune 1000 firms. Kaplan and Norton (2001) also report that the BSC has been adopted by not only profitoriented organizations, but also nonprofit organizations and government entities. Moreover the results of an unpublished survey conducted by the researcher to part-time MBA students who took a Management Control System class at Universitas Gadjah Mada in 2007 indicated that 68 percent of the respondents report that their firms have employed the BSC in various forms to measure business unit managers' performance.

The purposes of this study is to examine the moderating effect of procedural justice on the effectiveness of employing the financial and nonfinancial dimensions of BSC as managers' performance measures in improving managerial performance. The study extends Lau and Sholihin (2005) study and completes Lau and Moser's study (2008) by evaluating the moderating effect of procedural justices on the relationship between the BSC measures and organizational commitment.
Procedural justice is expected to strengthen the effect of employing the BSC measures on managers' commitment. It also examines the impact of commitment on performance. The first objective of this study is to complete Lau and Moser's (2008) study by employing the four perspectives of the BSC measure in judging managerial performance. Using the structural equation analysis, they map the direct and indirect relationships between nonfinancial measures (three of the four BSC performance perspectives): procedural fairness, organizational commitment, and managerial performance. They found the effect of nonfinancial measures on managerial performance is indirect via organizational commitment and procedural justice.

Lau and Sholihin (2005) documented that the four BSC perspectives significantly affect managers' behavior. The use of the BSC perspectives (financial and non-financial) indirectly affects job satisfaction through fairness of the measures and trust between supervisor and supervisee. This indirect relationship is strengthened by the insignificant direct relationship between the BSC measures and job satisfaction. However, Lau and Buckland (2001) and Lau and Mosser (2008) found inconsistent evidence regarding the effects of financial and nonfinancial measures on procedural justice. Lau and Buckland (2001) documented that financial measures represent objective and truthful measures and that they are perceived more fair than nonfinancial measures, which represent 
Supriyadi-The Moderating Effect of Procedural Justice on the Effectiveness of the BSC....

subjective and bias measures. On the other hand, Lau and Mosser (2008) indicated that nonfinancial measures represent complete and accurate measures and, that why they are perceived more fair than financial measures, which represent narrow and rigid measures.

Furthermore, since evaluating managerial performance is a process, then the fairness in evaluation procedures will be perceived through the length of the evaluation process and that is why the fairness of the procedures might be gradually perceived during the process, not as a consequence of the process. Hence, the fairness in evaluation process is not mediating but moderating the relationship between the BSC measures and manager's job satisfaction, as explained by the contingency theory (Fiedler 1983). The second objective of this study is to address this issue by evaluating the moderating effect of procedural justice on the effectiveness of the BSC performance measures.

Finally, the last objective of the study is to investigate the relationships of the variables of interests using multiple regression approach since the theory (contingency theory) and logical reasons as basis for modeling the relationships between variables exist. Lau and Sholihin (2005) and Lau and Moser (2008) nicely map the one-way relationship among variables of financial measures, nonfinancial measures, procedural fairness, organizational commitment, and managerial perfor- mance using structural equation analysis. They find significant relationships among variables, but in fact their relationships model among variables is complicated and is difficult to interpret to the real business conditions.

The study conducts surveys using 76 part-time MBA students at Gadjah Mada University as a sample. First, it predicts that procedural justice will strengthen the positive relationship between nonfinancial (financial) measures and organizational commitment. Second, it also expects that organizational commitment will positively affect managerial performance. The results of the study show that managers' perceptions on the procedural justice of the use of the financial and nonfinancial dimensions of BSC significantly strengthen the relationship between nonfinancial measures and organizational commitment (supporting Lau and Moser 2008), and between financial measures and organizational commitment (supporting Lau and Sholihin 2005). Finally, the study also finds that the relationship between organizational commitment and managerial performance is positive.

The remaining paper is organized as follows. The next section describes the theoretical background and hypothesis development in addressing the research issues. This is followed by an explanation of the research method employed and presentation of the results. The last section provides the conclusions and limitations of the study. 
Gadjah Mada InternationalJournal of Business, September-December 2010, Vol.12,No.3

\section{Literature Review and Hypothesis Development}

\section{The Balance Scorecard}

The BSC system provides a complete view of business unit performance based on a set of financial and non-financial measures, namely financial, customer relationships, internal business processes, and learning and growth performances. Kaplan and Norton (1996a) include a diverse set of performance measures in order to completely derive the business unit strategy into a cause-and-effects relationship between the strategy and the performance measurement. However, some researchers have identified conditional aspects that may influence the way evaluators in considering the BSC measures when they assess and judge manager's performance in implementing business unit strategies (Liedtka et al. 2008). For instance, since the BSC measures usually reflect similar measures across business units (common measures) and specific measures to each business unit (unique measure), Slovic and McPhillamy (1974) suggest that decision makers (evaluators) will focus on common measures and underuse of unique measures. Lipe and Salterio (2000) using experimental design conclude that most of the participants only consider common measures, ignoring unique measures when they compare performance of two different business units.

Some factors have been indicated to affect evaluators' judgmental bias in assessing managers' performance using the BSC. Kaplan and Norton (1996b) suggest that the lack of alignment between compensation and the BSC performance measurement systems may affect the effectiveness of implementing the BSC. Lipe and Salterio's (2000) experimental research concludes that general human cognitive tendencies are the main cause of the judgmental bias, while Liedtka et al. (2008) indicate that evaluators' individual characteristics - ambiguity intolerance - influence the BSC-based evaluation bias. These various results suggest that further research is needed to modify or clarify the BSC-based performance evaluation procedures (Liedtka et al. 2008).

In the development of the BSC performance measures, Kaplan and Norton (1996a) suggest to use a philosophy of cause-and-effect relationship when deriving outcome measures from strategies. Specifically, the four perspectives of the BSC are inseparable performance measures with the logic flow that internal business performance will affect learning and growth, that learning and growth performance will affect the customer, and finally that customer performance will affect financial performance. Hence, when managers' performance will be assessed using the BSC measures, they will consider the four perspectives of the BSC as important measures. This is the key success of using the BSC as a performance measurement system (Anthony and Govindarajan 2005). 
Supriyadi-The Moderating Effect of Procedural Justice on the Effectiveness of the BSC....

Moderating Effect of Procedural Justice

Procedural justice ${ }^{1}$ refers to the fairness of the managerial performance measurement process used to judge, evaluate, and reward subordinates' performance (McFarlin and Sweeney 1992; Lind and Tyler in Lau and Sholihin 2005; and Greenberg 1987). Procedural justice theory is expanded from the equity theory for resource allocation process (Greenberg 1987). Similarly, Laventhal (1980) suggests that fairness of the judgmental process toward decision-making will be reflected into the procedural justice of the decision process. That is, procedural fairness refers to fairness of the processes that leads to a decision outcome. The rules of procedural justices suggested by Laventhal (1980) include consistency, representativeness of interested parties, evaluativeness, accurate information, non-bias decision maker, and conformity to moral values.

Earlier studies documented that there are various ways to relate the effects of procedural justice on managerial performance (Libby et al. 2004; Wentzel 2002, and Libby 1999; among others). Folger (1987) documented that each of the organizational justices, e.g. procedural justice and distributive justice, is independently related to attitude toward the decision and the orga- nization. On the other hand, Korsgaard and Roberson (1995) found that regardless of the fairness of the decision, procedural justice will promote positive behavior of the related parties. Based on a meta-analysis of twentyfive years of organizational justice researches, Colquitt et al. (2001) documented that procedural justice had moderate correlations with system-referenced evaluation of authority. This result indicates that procedural justice within managerial performance evaluation consistently affects managerial performance. However, the effect is various between two ends of direct vs. indirect effects.

In the context of the BSC, the combination of financial and non-financial performance measures is to relate between short-term operational control and the long-term vision and strategy of the business (Kaplan and Norton 1992, 1996a, 2001). The BSC employs a multi-dimensional approach by including both financial and nonfinancial measures in order to combine the more traditional control methods (financial measures) with the new firm's emerging success-leading-indicators (non-financial measures) (Otley 1999). Amir and Lev (1996) concluded that the non-financial measure will increase the value-relevant of the financial measures related to the value of the subject telephone-company. Therefore, the study employs the two

\footnotetext{
${ }^{1}$ This study uses the term "justice" and "fairness" interchangeably. Some prior studies also used both of the terms in their studies (Linquist 1995; Lau and Sholihin 2005; among others). In this study, however, the term "procedural justice" is used when it refers to variable under examination.
} 
perspectives, financial and non-financial measures in implementing the BSC since both perspectives might appropriately not be used separately.

It has been documented that the use of the BCS in evaluating managerial performance is closely related to the managers' perception on the fairness of performance evaluation process. Referring to Laventhal's procedural justice rules (1980), the financial measures relate to the consistency rule since the measures are consistently applied across time and persons or divisions, while the non-financial measures relate to the representativeness rule since they represent the values, concerns and perspectives of each division. Furthermore, both the financial and non-financial measures also accommodate the rules of evaluativeness, accurate information, non-bias decision maker, and conformity to moral values.

However, managers may perceive procedural justice differently between nonfinancial and financial measures since both measures have different chcharacteristics. Lau and Buckland (2001) show that managers perceive financial measures as more fair than nonfinancial measures because financial measures are objective and truthful, while nonfinancial measures are subjective and biased. On the other hand, Lau and Mosser (2008) indicate managers perceive nonfinancial measures as more fair than financial measures since nonfinancial measures are complete and accaccurate, while financial measures are narrow and rigid.
One possible reason explaining this inconsistent evidence is the importance of the process in evaluating performance. Since measuring managers' performance using the BSC is a process, then the fairness in evaluation procedures will be perceived through the length of the evaluation process. Hence, managers will gradually perceive procedural justice during the process, not as a consequence of the process.

The study proposes that nonfinancial measures are associated with organizational commitment and the effect is strengthened when managers perceive the evaluation process as fair. Lau and Moser (2008) identify the three-relationships between nonfinancial measures, procedural fairness, and organizational commitment. They find that nonfinancial measures positively and directly affect organizational commitment, while they also positively and indirectly affect organizational commitment through procedural fairness. Fisher (1992) documents that since nonfinancial measures are broader terms, long-term dimensions, and tailor-made to conditions, they can result in a variety of possible measures. Consequently, they may affect user judgments in assessing performance. Therefore, managers' perception on how objectively nonfinancial measures are being used to evaluate their performance is expected to affect effectiveness of using nonfinancial measures to improve managers' organizational commitment. The study proposes the first hypothesis as follows. 
Supriyadi-The Moderating Effect of Procedural Justice on the Effectiveness of the BSC....

$H_{a l}:$ Managers' perception on procedural fairness of performance evaluation criteria strengthens the relationship between nonfinancial criteria and managers' organizational commitment

Kaplan and Norton (1996a) argue that the financial measures are able to summarize the readily measurable and important economic consequences of the actions of division managers. Furthermore, the financial measures will reflect the ability of managers to implement its division strategy that will contribute to the bottom-line of the company goal, profits (Kaplan and Mackey 1992 and Kaplan and Norton 1996b). Hence, the study proposes that the procedural justice is expected to positively improve the effectiveness of using financial measures to improve managers' organizational commitment. The study states the second hypothesis as follows.

$H_{a 2}:$ Managers' perception on procedural fairness of performance evaluation criteria strengthens the relationship between financial criteria and managers' organizational commitment.

Some earlier researches in behavioral aspects of performance measurement systems and participative budgeting have consistently documented that organizational commitment mediates the relationship between some behavioral effort variables and organizational performance (Lau and Moser 2008; Lau and Sholihin 2005; Porter et al. 1974; Mowday et al. 1979; among others). Organizational com- mitment is the strength of employees' involvement in a particular organization. The concepts of organizational commitment can be referred to as the condition with which employees will stay with the organization because they need to, because they are obligated to, or because they want to (Jaros et al. 1993). The third concept that is also called affective commitment is the most adopted concept, and hence, the study uses the third concept as suggested by Cohen (1993) and Cohen (1987).

Meyer at al. (1989) found a positive causal relationship between organizational commitment and organizational performance. They differentiate organizational commitment into affective and continuance commitment. Affective commitment refers to emotional attachment to, identification with, and involvement in the organization, while continuance commitment refers to perceived costs associated with leaving the company. They documented that affective commitment correlated positively and continuance commitment correlated negatively with job performance. Accordingly, the study proposes the third hypothesis as follows.

$H_{a 3}$ : Managers' organizational commitment is positively related to managers' managerial performance

Figure 1 displays the research model used to examine the relationship among variables of interests in the study. It proposes that procedural justice will be moderating the effects of using the BSC (nonfinancial and fi- 
Figure 1. Relationship between Nonfinancial measures, Financial Measures, Organizational Commitment, and Managerial Performance

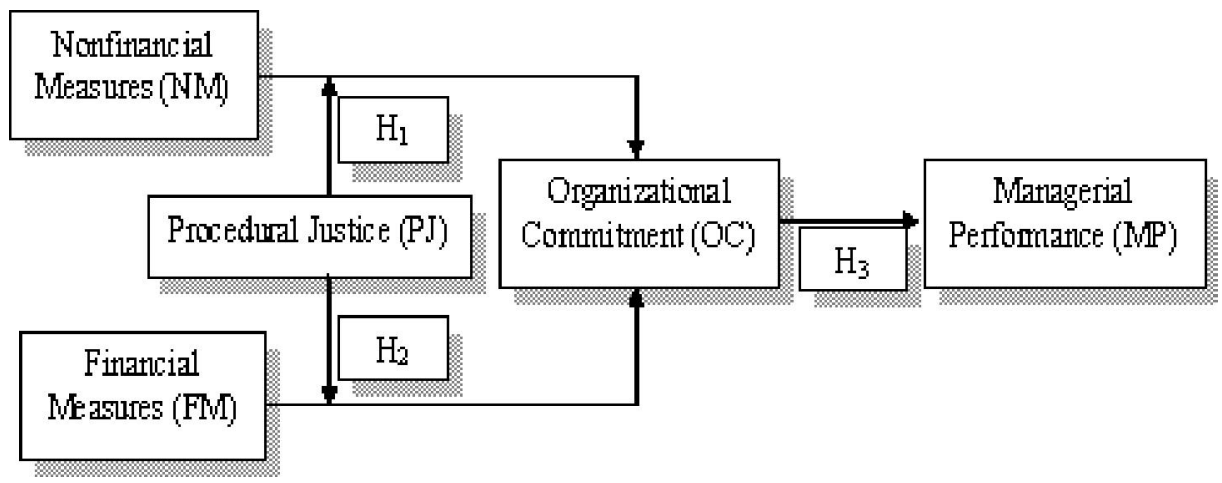

nancial measures) on organizational commitment. Finally, the organizational commitment, in turn, will affect managerial performance.

\section{Methodology}

\section{Respondents}

The hypotheses are tested using primary data collected from part-time MBA students at Universitas Gadjah Mada, Indonesia. There are $76 \mathrm{stu}-$ dents in three classes of management control systems subject (MCS) in the academic years of 2007/2008 and 2008/ 2009 who participate in the study. The selection of students in MCS classes is to assure that the respondents have basic knowledge of and are familiar with the topic and being asked about the use of BSC in the performance measurement system. The researcher distributes questionnaires to the respondents at the last session of the class meeting. The researchers put the questionnaires in the front of the class and announce to the students that there is a study asking the students who are willing to voluntarily participate in the study related to the BSC performance measurement system to take a questionnaire and fill it out before the class begins. It is also announced that it will take around 15-20 minutes to fill out the questionnaire, and that the study does not have any relationship with the MCS class.

The questionnaire is accompanied by a cover letter describing the objective of the study and assurance of response confidentiality. After the cover letter, the second page of the questionnaire asks the respondent to write a brief description of demography data, followed by a description of a mission, strategy, and the plan of using the BSC by the business unit to measure effectiveness of strategy implementation, questions relating to measuring variables in interests on the third to sixth pages, consecutively. Seventy nine students from 108 listed students $(70.37 \%)$ in the three MCS-classes participate in thestudy. Three responses are excluded from further analysis due to incom- 
Supriyadi-The Moderating Effect of Procedural Justice on the Effectiveness of the BSC....

Table 1. Distribution of Demography Data for Respondents

\begin{tabular}{lccc}
\hline & Man & Woman & Total \\
\hline Number of Repondents & $43(57 \%)$ & $33(43 \%)$ & $76(100 \%)$ \\
Average Age & 34 years & 30 years & 33 years \\
Working Experience & 10 years & 9 years & 10 years \\
Company Background: & & & \\
- Manufacturing & $6(8 \%)$ & $2(3 \%)$ & $8(11 \%)$ \\
- Services & $28(37 \%)$ & $17(22 \%)$ & $45(59 \%)$ \\
- Financial & $9(12 \%)$ & $14(18 \%)$ & $23(30 \%)$ \\
Holding Managerial Function & $40(53 \%)$ & $31(41 \%)$ & $71(94 \%)$ \\
\hline
\end{tabular}

plete or incorrect responses, and hence leaving 76 usable responses, of which 57 percent of them are men and 43 percent are women. The non-response bias among different times in three different classes is tested based on mean comparisons for the four variables used in the study (Hair 2006). The results show that there are no significant differences among means from three MCS classes.

Table 1 depicts the distribution of demography data. The average age of respondents is 33 years with an average working experiences of ten years, the shortest working experience of four years and the longest working experience of fourteen years. Most of the respondents $(94 \%)$ are involved in the managerial function of monitoring, evaluating, and/or supervising subordinates in their current positions. This condition indicates that most of the respondents have enough experiences functioning as a manager in their companies. Finally, 89 percent of respon- dents work in the service industry $(59 \%$ in general and $30 \%$ in financial services) and 11 percent work in the manufacturing industry.

\section{Variables Measurement}

\section{The BSC Measures}

The purpose of the study is to examine individual behavior responses to the four perspectives of performance measures used in the BSC, namely learning and growth, internal business, customer, and financial perspectives. The study employs four items of performance measures for each perspective (sixteen items for all perspectives) used by Lipe and Salterio (2000) with view wording modifications. However, the study selects only a set of the BSC measures for one division (ReadWear division) used by Lipe and Salterio's (2000) study, since it is more appropriate with Indonesian business environments. They use two sets of the BSC measures for two different divisions 
because their subjects are asked to compare the performance of two divisions using the BSC measures.

The study selected Lipe and Salterio's (2000) instrument based on three reasons. First, as suggested by Kaplan and Norton (1996), Lipe and Salterio's instrument has been specifically developed based on division strategy introduced in their experiment. Second, they decided to select sixteen items of measures based on the consideration that individual cognitive capacity to appropriately process cues of information is between fifteen to twenty cues. Moreover, Lipe and Salterio(2000) and Liedtka et al. (2007) indicate that measuring individual performance based on too few variables may not represent the real conditions; however, employing too many variables may complicate the process. The final reason is that Lipe and Salterio (2000) have done a pilot testing for their instrument to groups of MBA and accounting students resulting in valid representative of the BSC categories.

The items for learning and growth perspectives are hours of employee training per employee, employee suggestions per employee, average tenure of sales personnel, and stores computerizing. The four items used in internal business perspective include returns to suppliers, average major brand names/store, average markdowns, and average orders filled within one week. The items used in customer perspective are repeat sales, returns by customer as percentage of sales, customer satisfaction rating, and captured cus- tomer. Finally, the four items for financial perspectives include return on sales, new store sales, sales growth, and revenue per sales visit.

The questionnaireasks the respondents, as a manager of the division, to rank the importance of each item of the BSC performance measures used by their superior to assess his/her division performance, using a seven-point Likert scale for each item, in which scale 1 indicates the least importance and scale 7 indicates the most importance. Similar to Lipo and Salterio (2000), the first part of the instrument describes the company mission statement, introduces the managers of the business unit, describes the business unit's strategy, and presents the BSC for the business unit. This scheme is done to focus the respondents on the importance of the BSC in assessing strategy implementation. Furthermore, bringing respondents' mindsets to understand business unit strategy before assessing the BSC performance measures will result in more appropriate judgment relating to the importance and fairness of the measures. However, while Lipe and Salterio (2000) ask their subject to indicate business unit performance on the scale of 0 to 100 points, this study asks the respondent to indicate the importance of the BSC measures using a 7-point Likert scale.

The results of factor analysis with varimax rotation show that 16 items load to four perspectives with eigenvalue greater than 1 for all perspectives, namely eigenvalue for learning 
Supriyadi-The Moderating Effect of Procedural Justice on the Effectiveness of the BSC....

and growth perspective is 2.705 , inter- four perspectives significantly correnal business is 2.094, customer is 2.015, spond to the BSC measurement perand financial is 1.687; and those ex- spectives. Additionally, all four items plain $16.96,13.09,12.50$, and 10.55 also significantly load to their respecpercent of variances for each measure, tive perspectives with loading factors respectively. These indicate that the ranging from 0.511 to 0.798 .

Table 2. Factor Analysis and Eigenvalue for all BSC Perspectives

\begin{tabular}{|c|c|c|c|c|}
\hline Measure & $\begin{array}{l}\text { Learning } \\
\text { and Growth }\end{array}$ & $\begin{array}{c}\text { Internal } \\
\text { Business } \\
\text { Process }\end{array}$ & Customer & Financial \\
\hline $\begin{array}{l}\text { Hours of employee training } \\
\text { per employee }\end{array}$ & 0.566 & & & \\
\hline $\begin{array}{l}\text { Employee suggestions } \\
\text { per employee }\end{array}$ & 0.511 & & & \\
\hline Average tenure of sales personnel & 0.607 & & & \\
\hline Stores computerizing & 0.775 & & & \\
\hline Returns to suppliers & & 0.514 & & \\
\hline Average major brand names per store & & 0.777 & & \\
\hline Average markdowns & & 0.558 & & \\
\hline Average orders filled within one wee & & 0.626 & & \\
\hline Repeat sales & & & 0.553 & \\
\hline Customer satisfaction rating & & & 0.593 & \\
\hline $\begin{array}{l}\text { Return by customer as a percent } \\
\text { of sales }\end{array}$ & & & 0.798 & \\
\hline Captured customer & & & 0.776 & \\
\hline Return on sales & & & & 0.604 \\
\hline New store sales & & & & 0.593 \\
\hline Sales growth & & & & 0.651 \\
\hline Revenue per sales visit & & & & 0.597 \\
\hline Eigenvalue & 2.705 & 2.094 & 2.015 & 1.687 \\
\hline Percentage of variance explained & 16.964 & 13.090 & 12.501 & 10.547 \\
\hline Cronbach alpha & 7.617 & 7.617 & 7.617 & 6.738 \\
\hline
\end{tabular}


Gadjah Mada InternationalJournal of Business, September-December 2010, Vol.12,No.3

Table 3. Descriptive Statistics of Variables Used in Hypothesis Testing

\begin{tabular}{|c|c|c|c|c|c|c|}
\hline \multirow[t]{2}{*}{ Variable } & \multirow[b]{2}{*}{ Mean } & \multirow{2}{*}{$\begin{array}{l}\text { Std. } \\
\text { Dev. }\end{array}$} & \multicolumn{2}{|c|}{$\begin{array}{l}\text { Actual } \\
\text { Range }\end{array}$} & \multicolumn{2}{|c|}{$\begin{array}{c}\text { Theoretical } \\
\text { Range }\end{array}$} \\
\hline & & & Min & $\operatorname{Max}$ & Min & Max \\
\hline Nonfinancial measure & 5.22 & 0.23 & 4.83 & 5.67 & 1.00 & 7.00 \\
\hline Financial measure & 5.59 & 0.28 & 5.00 & 6.00 & 1.00 & 7.00 \\
\hline Procedural justice & 3.50 & 0.20 & 3.00 & 3.75 & 1.00 & 5.00 \\
\hline Organizational commitment & 6.82 & 0.08 & 6.67 & 6.89 & 1.00 & 7.00 \\
\hline Managerial performance & 5.58 & 0.78 & 4.00 & 7.00 & 1.00 & 7.00 \\
\hline
\end{tabular}

In the analysis, the nonfinancial perspective scores (customers, internal business, and learning and growth perspectives) are combined into one variable. The data used for regression analysis (hypothesis tests) is the average scores of raw data for each variable of interest, except for a managerial performance variable (see explanation under sub-heading of Managerial Performance). The average of nonfinancial performance is the mean of 16 items' scores of nonfinancial performance measures, the average score of financial performance is the mean of the four items' scores of financial performance measures, the average score of procedural justice is the mean of the four items' scores of procedural justice measures, and the average score of organizational commitment is the mean of the nine items' score of organizational commitment measures. Table 2 presents the results of factor analysis and eigenvalue for validity test of the instruments and Table 3 provides the descriptive statistics of all variables used in the regression analysis.

\section{Procedural Justice}

Using the BSC measures to judge overall managers' performance will involve subjective perceptions of the user on "the meaning" of the BSC measures. This condition is likely to affect the ethical (justice) perception of managers being evaluated using the BSC. Two forms of justice may be involved in the process, namely distributive justice and procedural justice. The concepts of distributive justice are developed based on the equity principle. It states that distributive justice sustains when the allocation of the outputs (benefits and/or costs) within a group is proportional to the contribution of group members. On the other hand, the concepts of procedural justice rely on the fairness of the rules and processes involved in the activity. The study relates to the justice perception of using the BSC (as a rule) to evaluate managers' performance (as a process). 
Supriyadi-The Moderating Effect of Procedural Justice on the Effectiveness of the BSC....

Hence, the interest of the study is the concepts of procedural justice.

Following Lau and Moser (2008) and Lau and Sholihin (2005), the study employs McFarlin and Sweeney's (1992) instrument to measure managers' perception of procedural justice. The questionnaires ask subjects to rating the procedural justice of performance evaluation process using a 5point Likert scale (1 has the least importance and 5 has the most importance) on four items used in the performance evaluation process. The four items include evaluating employee per- formance, determining employee promotions, determining salary increases, and communicating performance feedback. Table 4 presents the results of the factor analysis of the four procedural justice items. The rotated factor loadings for these items of procedural justice range from 0.559 to 0.759 and load on a single factor with an eigenvalue of 1.679 that explains 41.923 percent of the variances. The mean score is 3.50 with the standard deviation of 0.20 (see Table 3 ), and Cronbach alpha of 0.717 indicating valid measures.

Table 4. Factor Analysis and Eigenvalue for Procedural Fairness and Organizational Commitment

\begin{tabular}{lcc}
\hline Items & $\begin{array}{c}\text { Organizational } \\
\text { Commitment }\end{array}$ & Procedural Fairness \\
\hline OC1 & 0.651 & \\
OC2 & 0.571 & \\
OC3 & 0.520 & \\
OC4 & 0.773 & \\
OC5 & 0.718 & \\
OC6 & 0.903 & \\
OC7 & 0.894 & \\
OC8 & 0.725 & \\
OC9 & 0.820 & 0.661 \\
PJ1 & & 0.675 \\
PJ2 & & 0.759 \\
PJ3 & & 0.559 \\
PJ4 & & \\
& & 1.679 \\
Eigenvalue & 1.718 & 41.923 \\
Percentage variance explained & 19.084 & 0.717 \\
Cronbach alpha & 0.936 & \\
\hline
\end{tabular}




\section{Organizational Commitment}

Similar to Lau and Moser (2008), the study employs Mowday et al.'s (1974) instrument to measure organizational commitment. The questionnaires ask subjects to rate their agreement on nine statements using a 7point Likert scale ( 1 is strongly disagree and 7 is strongly agree) such as "I tell my friends that this organization is a great place to work for" and "I am proud to tell others that I am part of this organization." Table 4 presents the results of the factor analysis of the nine organizational commitment items. The rotated factor loadings for these items range from 0.520 to 0.903 and load on a single factor with an eigenvalue of 1.718 that explains 19.084 percent of the variances. The mean score is 6.82 with the standard deviation of 0.08 (see Table 3), and Cronbach alpha of 0.936 indicating valid measures.

\section{Managerial Performance}

The study employs Moahoney's (1963) managerial performance instrument that has been widely used in prior studies (Lau and Moser 2008; Lindquist 1995; and Brownell 1982; among others). The questionnaires ask subjects to rate nine-dimensions of areas of managerial performance using a 7-point Likert scale ( 1 is strongly disagree and 7 is strongly agree). These dimensions are planning, coordinating, evaluating, investigating, supervising, staffing, negotiating, representing, and overall performance.

As suggested by Brownell (1982) and also used by Lau and Moser (2008), the study uses the overall performance score as a measure of manager performance. Hence, to provide assurance that the measure reflects the eight dimension scores, the researcher regress the eight performance dimensions (as independent variables) on overall score (as dependent variables). The results show that the eight performance variables can explain around 58.8 percent of the variance in the overall performance variable, and this exceeds the minimum benchmark of 55 percent suggested by Mahoney et al. (1963). The mean score for managerial performance is 5.58 with the standard deviation of 0.78 (see Table 3 )

\section{Hypothesis Tests}

This study expects that procedural justice will strengthen the relationship between the BSC measures (financial and nonfinancial) and the organizational commitment. It is also expected that the organizational commitment will positively and significantly affect managerial performance. Regression analyses are used to test the hypotheses. Equation 1 depicts these two regression models.

$$
\begin{aligned}
& \text { Equation 1. } \begin{array}{l}
\text { The Multiple and } \\
\text { Simple Regression } \\
\text { Models }
\end{array} \\
& \mathrm{OC}=\alpha_{0}+\alpha_{1} \mathrm{NM}+\alpha_{2} \mathrm{FM}+\alpha_{3} \mathrm{PJ} \\
& +\alpha_{4} \mathrm{NM} \mathrm{PJ}+\alpha_{5} \mathrm{FM} * \mathrm{PJ}+\varepsilon_{1} \\
& \mathrm{MP}=\beta_{0}+\beta_{1} \mathrm{OC}+\varepsilon_{2}
\end{aligned}
$$

where:

$\mathrm{OC}=$ organization commitment 
Supriyadi-The Moderating Effect of Procedural Justice on the Effectiveness of the BSC....

$\mathrm{NM}=$ nonfinancial measure

$\mathrm{FM}=$ financial measure

$\mathrm{PJ}=$ procedural justice

$\mathrm{MP}=$ managerial performance

The first hypothesis is supported when $\alpha_{4}$ is significant with a positive sign. Similarly, the second hypothesis is supported when $\alpha_{5}$ is significant with a positive sign, while the last hypothesis is supported when $\beta_{1}$ is also significant with a positive sign.

\section{Results of Hypothesis Tests}

The study runs the regression model using SPSS version 15.0. Table 5 presents the results of running the moderating regression model based on 76 observation data. The descriptive statistics for the data used in the regression models are presented in Table 3.

The results of regressing the moderating model indicate that the model is reliably used to test the hypotheses with the goodness of fit $F$-value of 9.788 and significant at $p$-value of 0.000 . All independent variables in the model can explain 36.9 percent variations in the organizational commitment (adjusted $\mathrm{R}^{2}=0.369$ ). Furthermore, all independent variables are also significant at $\mathrm{a}=1$ percent (except variable Nonfinancial Measure * Procedural Justice at $a=5 \%$ ). Interestingly, all the coefficient relationships between the main individual variables of nonfinancial measure, financial measure, and procedural justice and organizational commitment have significant negative signs, while earlier studies document positive signs. When a one-tail t-test isused with the expectation of positive direction, then the negative coefficient will be considered as insignificant. These results reflect that procedural justice is neither related to the BSC measures nor organizational commitment, but it interacts with the BSC measures to modify the relationship form of the BSC measures and organizational commitment (Sharma et al. 1981). Thus, the procedural justice can function as a pure moderator variable in the relationship. ${ }^{2}$

Table 5 also shows that the coefficient of (Nonfinancial Measure * Procedural Justice) is 0.986 with tvalue of 2.348 and at a of 5 percent indicating strong support to the first hypothesis. As expected procedural justice significantly strengthens the positive effect of using the nonfinancial measure when assessing manage-

\footnotetext{
2 The moderating model is robust since there are insignificant direct relationship between organizational commitment and nonfinancial measures (coefficient 0.021 , t-value 0.564 , and pvalue 0.574); organizational commitment and financial measures (coefficient -0.030 , t-value 0.942 , and p-value 0.349 ); organizational commitment and procedural justice (coefficient 0.180 , tvalue 0.416 , and p-value 0.678); and nonfinancial measures and procedural justice (coefficient 0.001 , t-value -0.002 , and p-value 0.998). The direct relationship between finanacial measures and procedural justice is significant, however, the sign is negative (coefficient $-0.256, \mathrm{t}$-value -3.275 , and p-value 0.002). This negative direct relationship is inconsistent with the finding in earlier studies.
} 
Gadjah Mada InternationalJournal of Business, September-December 2010, Vol.12,No.3

Table 5. The Results of the Organizational Commitment (OC) Moderating Regression Model

\begin{tabular}{|c|c|c|c|c|}
\hline Variable & Beta & $\begin{array}{c}\text { Std. } \\
\text { Error }\end{array}$ & t-value & p-value \\
\hline Constant & 34.808 & 8.188 & 4.251 & 0.000 \\
\hline Nonfinancial Measure & -3.966 & 1.458 & -2.721 & 0.008 \\
\hline Financial Measure & -2.205 & 0.699 & -3.155 & 0.002 \\
\hline Procedural Justice & -7.258 & 2.337 & -3.105 & 0.003 \\
\hline Nonfinancial Measure * Procedural Justice & 0.986 & 0.420 & 2.348 & 0.022 \\
\hline Financial Measure * Procedural Justice & 0.616 & 0.199 & 3.096 & 0.003 \\
\hline $\mathrm{R}^{2}$ & 0.411 & & & \\
\hline Adjusted $\mathrm{R}^{2}$ & 0.369 & & & \\
\hline F-value & 9.788 & -value: 0 & 000) & \\
\hline
\end{tabular}

Table 6. The Regression Results of the Managerial Performance (MP) Model

\begin{tabular}{lrrrr}
$\mathbf{M P}=\boldsymbol{\beta}_{\mathbf{0}}+\boldsymbol{\beta}_{\mathbf{1}} \mathbf{O C}+\varepsilon_{\mathbf{2}}$ & Beta & $\begin{array}{c}\text { Std. } \\
\text { Error }\end{array}$ & t-value & $\mathbf{p}$-value \\
\hline Variable & -48.533 & 5.183 & -9.363 & 0.000 \\
& 7.978 & 0.760 & 10.498 & 0.000 \\
Constant & 0.598 & & & \\
Organizational Commitment & 0.593 & & \\
$\mathrm{R}^{2}$ & 110.214 & (p-value: 0.000$)$ \\
Adjusted R & & & \\
F-value & &
\end{tabular}

rial performance through organizational commitment. Similarly, the results also significantly support the second hypothesis when the coefficient of (Financial Measure * Procedural Justice) is 0.616 with t-value of 3.096 and at the a of 1 percent. As expected procedural justice significantly strengthened the positive effect of using the financial measure when assessing managerial performance through organizational commitment. These results support earlier studies done by, among others, Lau and Mosser (2008) and Lau and Sholihin (2005). Hence, introducing procedural justice into the 
Supriyadi-The Moderating Effect of Procedural Justice on the Effectiveness of the BSC....

process of managerial performance measurement systems will improve the effectiveness of implementing the BCS as a part of performance evaluation system.

Table 6 presents the simple regression results to test the third hypothesis that managers' organizational commitment is positively related to managers' managerial performance. The results of the regression indicate that the model is reliably used to test the hypotheses with the goodness of fit F-value of 110.214 and significant at $\mathrm{p}$-value of 0.000 . The independent variable in the model can explain 59.3 percent variations in the managerial performance (adjusted $\mathrm{R}^{2}=0.593$ ). As expected the coefficient of organizational commitment (7.978) was positively significant with $t-v a l u e ~ o f ~ 10.498$ and p-value of 0.000 supporting hypothesis three.

\section{Conclusion, Discussion, and Limitation}

The aim of this study is to examine the moderating effects of procedural justice on the effectiveness of the BSC performance measures in improving managerial performance through organizational commitment. The study remodels the mediating effect of procedural justice on the relationship between the BSC measure and managerial performance found in prior studies, into the moderating effect based on the contingency theory.

The results of this study support previous studies in organizational and managerial accounting areas on the effect of procedural fairness on individual manager or employee behavior (Wentzel 2002; Libby 1999; Magner et al. 1995; Lindquist 1995; and McFarlin and Sweeney 1992; among others). However, this study extends prior studies by remodeling the role of procedural justice and providing empirical evidence. While the earlier studies indicate the role of procedural justice as a mediating variable on the relationship between management performance measure and managerial performance, this study proposes the procedural justice as moderating variable on the relationship. Empirical evidence strongly supports the proposition in this study that procedural justice has a pure moderating role.

There are some cautions to interpret the results of the study due to the following limitations: First, there is an inherent embedded limitation of using a survey method especially related to the possibility of missing appropriate context and of lacking respondents' knowledge. However, the use of an empirically tested valid instrument and experienced respondents in this study are expected to mitigate these drawbacks. Future studies may consider these drawbacks by employing other methods, such as field or laboratory experiments. Secondly, the study does not separate the dimensions of the nonfinancial measures of the BSC into three perspectives, learning and growth, internal business, and customer perspectives, as developed by Kaplan and Norton (1992). Combining the 
Gadjah Mada InternationalJournal of Business, September-December 2010, Vol.12,No.3

three perspectives into one dimension may reduce the appropriateness of the measure when, in fact, respondents interpret the measures differently. Fu- ture studies can deal with this limitation by separating the nonfinancial measures into three dimensional measures.

\section{References}

Amir, A., and B. Lev. 1996. Value relevance of nonfinancial information: The wireless communications industry. Journal of Accounting and Economics 22: 3-30.

Anthony, R. N., and V. Govindarajan. 2005. Management Control Systems (1 $11^{\text {th }}$ Ed.) Chicago, IL: Irwin.

Brownell, P. 1982. The role of accounting data in performance evaluation, budgetary participation, and organizational effectiveness. Journal of Accounting Research 20 (1) Spring: 12-27.

Cohen, R. L. 1987. Distributive justice: Theory and research. Social Justice Research 1 (1): $19-40$.

Cohen, A. 1993. Organizational commitment and turnover: A meta analysis. Academy of Management Journal 36 (5): 1140-1157.

Colquitt, J. A., D. E. Conlon, M. J. Wesson, C. O. L. H. Porter, and K. Yee Ng. 2001. Justice at the Millennium: A meta-analytic review of 25 years of organizational justice research. Journal of Applied Psychology 86 (3): 425-445.

Fiedler, F. E. 1983. 'Assessing the validity of fiedler's contingency model of leadership effectiveness: A closer look at Strube and Garcia.' Psychological Bulletin 93: 4048.

Fisher, J. 1992. Use of nonfinancial performance measures. Journal of Cost Management (Spring):31-38.

Folger. 1987. Distributive and procedural justice in the workplace. Social Justice Research 1 (2): 143-160.

Greenberg, J. 1987. A taxonomy of organisational justice theories. Academy of Management Review 12 (1): 9-22.

Hair, J. F., R. L. Tatham, R. E. Anderson, and W. Black. 2006. Multivariate Data Analysis. New Jersey: Prentice Hall.

Jaros, S., J. Jermier, J. Koehler, and T. Sincich. 1993. Effects of Continuance, affective and moral commitment on the withdrawal process: An evaluation of eight structural equation models. Academy of Management Journal 36: 951-995.

Kaplan, S. E., and J. T. Mackey. 1992. An examination of the association between organizational design factors and the use of accounting information for managerial performance evaluation. Journal of Management Accounting Research 4: 116-130.

Kaplan, R. S., and D. P. Norton. 1992. The balanced scorecard - measures that drive performance. Harvard Business Review 70 (1): 71-79. 
Supriyadi-The Moderating Effect of Procedural Justice on the Effectiveness of the BSC....

1993. Putting the balanced scorecard to work. Harvard Business Review 71 (5): 134-42.

. 1996a. Using the balanced scorecard as strategic management system. Harvard Business Review 74 (1): 75-85.

. 1996b. The Balanced Scorecard: Translating Strategy into Action. Boston, MA: Harvard Business School Press.

- 2001. Transforming the balanced scorecard from performance measurement to strategic management: Part 1. Accounting Horizons 15 (1): 87-104.

Korsgaard, M. A., and L. Roberson. 1995. Procedural justice in performance evaluation: The role of instrumental and non-instrumental voice in performance appraisal discussions. Journal of Management 21 (4): 657-669.

Lau, C. M., and A. Moser. 2008. Behavior Effects of Nonfinancial Performance Measures: The Role of Procedural Fairness. Behavioral Research in Accounting 20 (2): 55-71.

Lau, C. M., and M. Sholihin, 2005. Financial and nonfinancial performance measures: How do they affect job satisfaction? The British Accounting Review 37: 389-413.

Lau, C. M., and E. Lim. 2002. The intervening effects of participation on the relationship between procedural justice and managerial performance. British Accounting Review 34: 55-78.

Lau, C. M., and C. Buckland, 2001. Budgeting-role of trust and participation: a research note. $A B A C U S$ 37: 369-388.

Lau, C. M., L. C. Low, and I. Eggleton. 1995. The impact of reliance on accounting performance measures on job-related tension and managerial performance: Additional evidence. Accounting, Organizations and Society 20 (5): 359-381.

Laventhal, G. S., J. Karuza Jr., and W. R. Fry, 1980. Beyond fairness: A theory of allocation preferences. In G. Mikula, Justice and Social Interaction: 167-218. Bern, Switzerland: Hans Huber Publishers.

Libby, T., 1999. The influence of voice and explanation on performance in a participative budgeting setting. Accounting, Organizations and Society 24 (2): 125-137.

Libby, T., S. E. Salterio, and A. Webb. 2004. The balanced scorecard: The effects of assurance and process accountability on managerial judgment. The Accounting Review 79 (4): 1075-1094.

Liedtka, S. L., B. K. Church, and M. R. Ray. 2008. Performance Variability, Ambiguity Intolerance, and Balanced Scorecard-Based Performance Assessments. Behavioral Research in Accounting 20 (2): 73-88.

Lindquist, T. 1995. Fairness as antecedent to participative budgeting: Examining the effects of distributive justice, procedural justice and referent cognitions of satisfaction and performance. Journal of Management Accounting Research 7: 122-147.

Lipe, M. G., and S. E. Salterio. 2000. The balanced scorecard: Judgmental effects of common and unique performance measures. The Accounting Review 75 (3): 283-298.

.2002. A note on the judgmental effects of the balanced scorecard's information organization. Accounting, Organizations and Society 27 (6): 531-540. 
Mahoney, T., T. Jerdee, and S. Carroll. 1963. Development of Managerial Performance: A Research Approach. Cincinnati, OH: South-Western Publishing Company.

Marr, B., Neely, A., Bourne, M., Franco, M., Wilcox, M., Adams, C., Mason, S., \& Kennerley, M. (2004). Business performance measurement - What is the state of use in large US Firms? Proceedings of PMA 2004 Conference. UK Edinburgh, July 2004.

McFarlin, D., and P. Sweeney. 1992. Distributive and procedural justice as predictors of satisfaction with personal and organizational outcomes. Academy of Management Journal 35 (3): 626-637.

Mowday, R. T., R. M. Steers, and L. W. Porter. 1979. The measurement of organizational commitment. Journal of Vocational Behavior 14 (2): 224-247.

Otley, D. T. 1999. Performance management: A framework for management control systems research. Management Accounting Research 10 (4): 363-382.

Porter, L. W., R. M. Steers, R. T. Mowday, and P. V. Boulian. 1974. Organizational commitment, job satisfaction, and turnover among psychiatric technicians. Journal of Applied Psychology 39 (5): 603-609.

Rigby, D. (2001). Management Tools and Techniques: A Survey. California Management Review 43 (2), 139-160.

Sharma, S., R. M. Durand, and O. Gur-Arie. 1981. Identification and Analysis of Moderator Variables. Journal of Marketing Research (August): 291-300.

Slovic, P., and D. MacPhillamy, 1974. Dimensional commensurability and cue utilisation in comparative judgment. Organisational Behavior and Human Performance 11: 172-194.

Wentzel, K. 2002. The influence of fairness perceptions and goal commitment on managers' performance in a budget setting. Behavioral Research in Accounting 14: $247-271$ 
